\title{
The Effects of COVID-19 in the Learning Process of Primary School Students: A Systematic Review
}

\author{
José Jesús Sánchez Amate, Antonio Luque de la Rosa*DiD, Rafaela Gutiérrez Cáceres and Alejandro Vargas Serrano \\ Department of Education, University of Almeria, 04120 Almeria, Spain; josejesus_sa@hotmail.com (J.J.S.A.); \\ rcaceres@ual.es (R.G.C.); alejandrovar@hotmail.com (A.V.S.) \\ * Correspondence: aluque@ual.es
}

Citation: Sánchez Amate, J.J.; Luque de la Rosa, A.; Gutiérrez Cáceres, R.; Vargas Serrano, A. The Effects of COVID-19 in the Learning Process of Primary School Students: A

Systematic Review. Educ. Sci. 2021, 11, 654. https://doi.org/10.3390/ educsci11100654

Received: 13 August 2021

Accepted: 14 October 2021

Published: 19 October 2021

Publisher's Note: MDPI stays neutral with regard to jurisdictional claims in published maps and institutional affiliations.

Copyright: (c) 2021 by the authors. Licensee MDPI, Basel, Switzerland. This article is an open access article distributed under the terms and conditions of the Creative Commons Attribution (CC BY) license (https:/ / creativecommons.org/licenses/by/ $4.0 /)$.

\begin{abstract}
Background: A variety of social and economic changes are happening worldwide due to the pandemic caused by COVID-19, which has produced new problems and challenges for the population as a whole. These events demand new investigations and key studies for their management. This review addresses the repercussions of COVID-19 at the educational level in the primary education stage, delving into the effects produced in teaching and different aspects related to it, such as the situation and challenges of teachers, family involvement, and the perceptions and repercussions of the learning and socio-educational development of students (especially in the case of students with Autism Spectrum Disorder). (2) Methods: The methodological design is a systematic review study, following the PRISMA guidelines, from a search carried out during the month of July 2021 in the Scopus, Dialnet, and WoS databases on the object of study. (3) Results: The selected studies were analyzed through a qualitative content analysis based on a population of 103 articles, with a final sample of 13, using the inclusion criteria: empirical studies or research in English or Spanish; free access through the Internet; categories restricted to "education/educational research" related to the proposed objectives; specific documents of the primary education stage and/or students with Autism Spectrum Disorder. (4) Conclusions: The research reveals the presence of an existing digital gap in certain sectors of the student population aggravated by the pandemic, as well as the scarcity of general teacher training in this type of situation, leading to different personal and professional problems that hinder teaching and emphasize the vulnerability of the right to education, which leads to further promoting the already existing social inequalities.
\end{abstract}

Keywords: COVID-19; educational problems; family; teachers; Autism Spectrum Disorder; primary education

\section{Introduction}

According to UNESCO (United Nations Educational, Scientific, and Cultural Organization) [1], the starting point of the new pandemic was Wuhan, the capital of Hubei, which belongs to central China. The date of its origin is estimated to be December 2019. The name established for this disease is COVID-19, known as a coronavirus type characterized by symptomatologies associated with severe acute respiratory syndrome (SARS-COV-2). The transmission of this virus is associated with the social relationship between people, placing its highest rate of contagion in direct person-to-person transmission. In order to prevent the spread of COVID-19, all the governments of the affected countries have decided to carry out different measures to control it.

From the educational point of view, the different modifications and alternatives proposed must be taken into account [2], with the aim of being able to cope with the inconveniences caused by the pandemic. According to different data sources related to the field of education, UNESCO points out the temporary closure of educational institutions by most governments, in an attempt to contain the spread of the pandemic. The total closure of institutions at the national level affects $91 \%$ of the world's educational population; this date 
was calculated on 12 April 2020, and shows signs of a possible increase in the future [1]. In the particular case of Spain, after Royal Decree 463/2020 was established on March 14 and the state of emergency was declared, there were more than ten million students who intend to complete their education at home. Therefore, in order to achieve this situation, the different educational administrations proposed a transition from face-to-face education to distance education, highlighting the uncertainty and doubts about how this transition is being carried out and the impact on the teaching and learning process for different student sectors [3].

Consequently, the unexpected global context produced by this pandemic has led to educational uncertainty, instability, and change [4]. Teachers have been affected by the unpredictability of events, and they have had to adopt certain methodological adaptations during a short period of time, in new scenarios used when teaching and disseminating content and, as a whole, in the development of the teaching process itself. Both educational institutions as a whole and teachers in particular have experienced such drastic change processes [5], which require modifications from the conceptual field of teaching itself, promoting changes and new strategies in the development of teaching, thus moving from face-to-face teaching to a new orientation based on an online instructional model. The objective pursued within these processes of change should focus on the search for educational quality through the new methodologies mentioned above, so we can ensure that this whole process has left its mark on the entire educational system [6]. Therefore, despite the fact that the described context presents different implications for the professional and personal environment of teachers and students, it must be established that for the pedagogical model to be successful, it must focus on overcoming fundamental aspects such as the implementation of technological resources, teacher training, and the adaptation of students to this new form of education [7].

In this regard, in order to understand the reality of what is happening and to make suitable proposals for action, we must consider the social, economic, political, and even cultural aspects of teachers, students, and families. Specifically, the introduction and acquisition of these new measures by teachers depends, significantly, on aspects such as their preparation and training [8], the skills acquired in their previous training, the emotions and attitudes they feel when working with ICT (Information and Communication Technologies), the importance they attach to the new work scenario, and the relevance of the incorporation of ICT in their work environment. Likewise, it is necessary to take into account the different family and cultural contexts of the students, taking into account the existence of different socioeconomic levels in families, which can make it more difficult for them to cope with the changes imposed by the new teaching methodology [9].

On the other hand, in line with the recognized diversity of the individual and the horizon of social and educational inclusiveness that our society has built, each student has different educational needs, which are changing and unique in each individual, becoming even greater in the current situation [10]. Faced with these needs, the Spanish educational system has established a set of personal and material resources to respond and enable maximum learning for each student. In this vein, we find certain groups of students with special educational needs (SEN), which is a concept that has been changing and has different connotations depending on the author, time, or context, but in any case wants to refer to this type of students who have some severe difficulties (lasting or temporary) during the teaching-learning process, behavioral problems, and maturational delays, among others, which require special attention when it comes to providing an educational response to their situation [11].

Therefore, this situation, characterized by the demand for transition of the educational model demanded by COVID-19 and carried out through the incorporation of ICT into the school system, has led to highlighting the institutional shortcomings in terms of the infrastructures of modern education. This implies the necessary reflection on how to advance in this change, moving toward the proper development of teaching, the new school practice, and the teacher training [12]. 
In this regard, in addition to considering more general aspects regarding the overall problems that COVID-19 has generated in primary education, our study aims to analyze the impact it has had on a type of students with SEN such as those with Autism Spectrum Disorder (ASD), since there are several indications to show that the severity of the incidence of the pandemic in this type of students is evident [11], based mainly on the characteristics that appear in the DSM-V, which indicate that this type of subject presents problems of communication and social interaction, and these factors are some of the most affected by the technological model. Likewise, this type of subject displays repetitive and limited patterns of behaviors, interests, and activities that affect their daily functioning [13] and that have suffered an increase as a consequence of confinement [14]. However, these repercussions do not only affect this group, since today, the limitations of mobility and social interaction have impaired the possibilities of development of everyone, affecting aspects such as social interaction, communication, and the limitation of routine behaviors, not only in the educational field but also in the social and psychological health of all students and all that this entails in their growth and social integration process [15].

In view of the above, the present research aims to determine the repercussions of the COVID-19 pandemic in the educational system, specifically taking into account primary school students, their teachers, the involvement of their families in this process, and, more specifically, the incidence of the pandemic in students with special educational needs; for this, we will exemplify the case of the special incidence in students with ASD, given the psychosocial characteristics of this group and the virulence of the effects that can be detected in it. In this sense, the research questions that this systematic review study aims to answer are the following:

- What are the effects of COVID-19 on the teaching-learning process of elementary school students?

- What are the main challenges presented by primary school teachers due to the pandemic generated by COVID-19?

- How does COVID-19 impact on the social and educational aspects of students with ASD in primary education?

\section{Method}

According to the objectives set, the method selected was a systematic review through Scopus, Dialnet, and WoS databases, whose purpose is to analyze the data in order to obtain an exhaustive overview of the information available on the subject under study. The selection of these databases was made based on their international prestige and recognition, as well as on their specific content in terms of research in the field of education [16]. After the search, compilation, and selection of some relevant articles, an analysis process was carried out by extracting descriptive information about the studies and their findings (author, aim, method, participants, and results), from which the evidence of the results obtained was contrasted with similar literature [17].

\subsection{Search Procedures}

The present systematic review is in accordance with the recommendations of PRISMA [18]. Using the WoS, Dialnet, and Scopus databases, a search for bibliographic documents was carried out during the month of July 2021 using a combination of the following descriptors: COVID-19 andeducation, COVID-19 andprimary education, COVID-19 and students, COVID-19 andchildren, COVID-19 andSEN, COVID-19 and ASD. The results of the initial search were limited to: full documents, open access documents, categories restricted to "education/educational research", specific documents from the primary education stage, and documents written in English or Spanish. At this initial stage, the search resulted in 195 articles. After the elimination of duplicates, the initial search was reduced to 103 articles (WoS: 7; Dialnet: 82; Scopus: 14).

In a first selection stage, the title and abstract of the 103 articles from the first search were analyzed by applying the inclusion criteria $(A),(B),(C)$, and (D), explained in the next 
section (Table 1). In this first selection, the search resulted in 34 articles included for the next stage. These articles were evaluated independently by two authors to verify their inclusion according to the established criteria. The initial concordance between the evaluators when the results of the two authors were compared after the complete reading was $98.76 \%$. Disagreements were resolved through discussion and consensus by the researchers until $100 \%$ agreement was reached. Figure 1 shows the literature search and selection process through a PRISMA flow chart.

Identification of studies via databases and registers
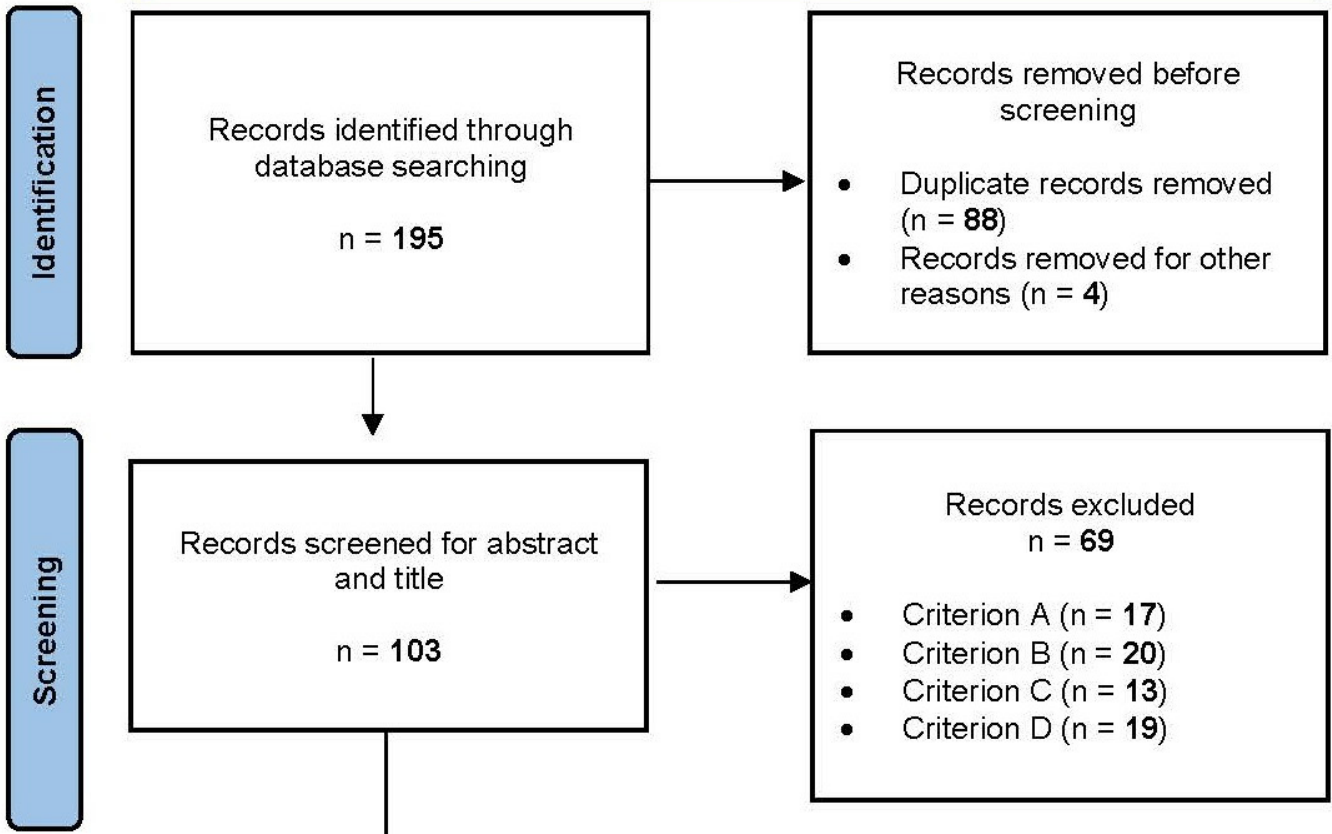

Records excluded $\mathrm{n}=69$

- Criterion $A(n=17)$

- Criterion $B(n=20)$

- Criterion $C(n=13)$

- Criterion D $(n=19)$
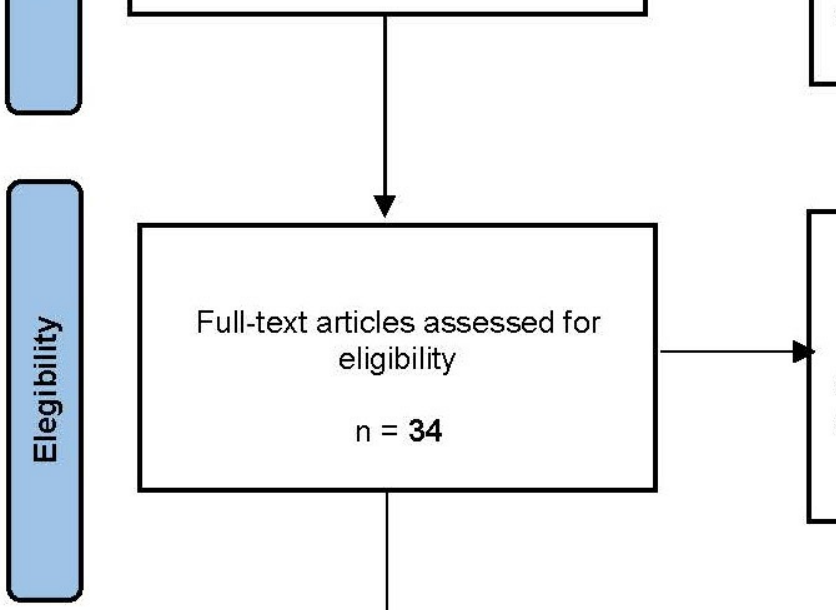

Records excluded $\mathrm{n}=\mathbf{2 1}$

- Criterion $C(n=14)$

- Criterion $D(n=7)$

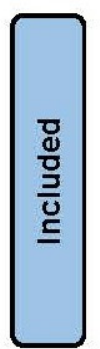

Unique studies included in final systematic review

$$
n=13
$$

Figure 1. PRISMA flowchart. 
Table 1. Selection criteria.

\begin{tabular}{ccc}
\hline Inclusion Criteria & Exclusion Criteria \\
\hline A & $\begin{array}{c}\text { Empirical studies or research in English } \\
\text { or Spanish published in peer-reviewed } \\
\text { scientific journals }\end{array}$ & $\begin{array}{c}\text { Rest of publications (documents whose } \\
\text { content is theoretical or related to } \\
\text { non-educational aspects, books, ... ) }\end{array}$ \\
\hline B & Free access through the Internet & No free access through the internet \\
\hline C & $\begin{array}{c}\text { Categories restricted to } \\
\text { "education/educational research" related } \\
\text { to the proposed objectives }\end{array}$ & $\begin{array}{c}\text { Papers related to other aspects not } \\
\text { included in the objectives of this study }\end{array}$ \\
\hline D & $\begin{array}{c}\text { Specific documents of the primary } \\
\text { education stage and/or students with } \\
\text { Autism Spectrum Disorder }\end{array}$ & $\begin{array}{c}\text { Studies or experiences in other } \\
\text { educational stages }\end{array}$ \\
\hline
\end{tabular}

Finally, as a result of this last phase, 13 articles have been included in this systematic review (Table 2), which have been analyzed from a double perspective: on the one hand, the descriptive information on the studies and their findings, and on the other hand, the quality of the studies included and the validity of the information provided, according to the inter-rater reliability indicated, to respond to some of the research objectives, by highlighting thematic aspects such as the impact of COVID-19 in primary education, the role of teachers during the pandemic, the repercussions of the new teaching-learning model, and the special impact on students with Autism Spectrum Disorders.

Firstly, it was agreed to focus only on articles, because these scientific works presumably contained more synthetic and detailed research on the subject under study. It was also considered to include articles in English or Spanish, although at the time of sear-ching, the results obtained that responded to the research questions were mostly in Spa-nish.

Similarly, it was considered appropriate to reduce the range of publication in the period between 2018 and 2021, in order to identify documents related to the impact of the pandemic on primary education and especially on students with Autism Spectrum Disorder. In addition, since the focus was on education, it was considered necessary to restrict the search to publications related to the area of educational research.

\subsection{Selection Criteria}

In order to identify the articles related to the topic under study, it was necessary to establish some inclusion criteria. These criteria were (A) empirical studies or research in English or Spanish; (B) free access through the Internet; (C) categories restricted to "education/educational research" related to the proposed objectives; and (D) specific documents of the primary education stage and/or students with Autism Spectrum Disorder. Scientific rigor was added to this research by including only peer review articles, thus excluding books, chapters, communications, and theses. These inclusion criteria were essential, as the main objective is to identify studies focused on the impact of COVID19 in primary education and its special impact on students with ASD. Therefore, those documents whose content was theoretical in nature or related to non-educational aspects were excluded. Likewise, they were not taken into consideration in the case of studies or experiences in other educational stages. 
Table 2. Description of studies included.

\begin{tabular}{|c|c|c|c|c|c|c|}
\hline $\mathbf{R Q}$ * & Author/Title & Year & Aim & Participants & Method & Results \\
\hline $\begin{array}{l}1 \\
\text { and } \\
2\end{array}$ & $\begin{array}{l}\text { Cáceres, Jiménez \& Martín } \\
\text { "Cierre de escuelas y desigualdad } \\
\text { socioeducativa en tiempos del } \\
\text { COVID-19. Una investigación } \\
\text { exploratoria en clave internacional" }\end{array}$ & 2020 & $\begin{array}{l}\text { To show an international } \\
\text { perspective that addresses the } \\
\text { process of school closures and } \\
\text { takes into account the possible } \\
\text { educational and social } \\
\text { consequences that may arise. }\end{array}$ & $\begin{array}{c}23 \\
\text { Countries }\end{array}$ & $\begin{array}{l}\text { Qualitative and quantitative, } \\
\text { with an exploratory approach. } \\
\text { Literature review and } \\
\text { statistical analysis. } \\
\text { Instruments: Questionnaire. }\end{array}$ & $\begin{array}{l}\text { It shows a great diversity of ways of dealing } \\
\text { with the situation, pointing out general aspects } \\
\text { to be taken into account such as equal } \\
\text { opportunities and educational equity of the } \\
\text { population. In addition, it shows a climate of } \\
\text { ignorance with future educational and social } \\
\text { prospects, with the greatest impact on the most } \\
\text { susceptible and vulnerable population. }\end{array}$ \\
\hline 2 & $\begin{array}{c}\text { Sevilla, Martín, \& Jenaro } \\
\text { “Actitud del docente hacia la } \\
\text { educación inclusiva y hacia los } \\
\text { estudiantes con necesidades } \\
\text { educativas especiales" }\end{array}$ & 2018 & $\begin{array}{l}\text { Analysis of teaching attitudes } \\
\text { toward the inclusion of students } \\
\text { with SEN. }\end{array}$ & 680 & $\begin{array}{l}\text { Qualitative and quantitative, } \\
\text { correlational type. } \\
\text { Instruments: Questionnaire. }\end{array}$ & $\begin{array}{l}\text { There is a generalized negative attitude of } \\
\text { teachers toward inclusive education, with } \\
\text { different geographic connotations and locating } \\
\text { several factors that affect teachers' attitudes. }\end{array}$ \\
\hline 2 & $\begin{array}{c}\text { Inga, García, Castro, \& Erazo } \\
\text { "Educación y COVID-19: } \\
\text { Percepciones docentes para enfrentar } \\
\text { la pandemia" }\end{array}$ & 2020 & $\begin{array}{l}\text { To know the teachers' perception } \\
\text { of the COVID-19 pandemic. } \\
\text { Psychosocial aspects and their } \\
\text { work as teachers. }\end{array}$ & 195 & $\begin{array}{l}\text { Quantitative, descriptive, and } \\
\text { correlational Approach. } \\
\text { Instruments: Questionnaire. }\end{array}$ & $\begin{array}{c}\text { Shows a large negative impact with respect to } \\
\text { the impact of the pandemic. General effects on } \\
\text { the personal and professional level of teachers } \\
\text { are noted, affecting the full development of } \\
\text { their profession due to factors such as lack of } \\
\text { knowledge, uncertainty, and the lack of } \\
\text { resources. }\end{array}$ \\
\hline 2 & $\begin{array}{l}\text { Sanahuja, Sánchez, \& Ruiz } \\
\text { "Estrategias de autorregulación y } \\
\text { personalización de la enseñanza: } \\
\text { estudio piloto sobre las competencias } \\
\text { de los profesionales de comunicación } \\
\text { y lenguaje y de educación especial" }\end{array}$ & 2020 & $\begin{array}{l}\text { To understand the training, } \\
\text { proficiency, and development of } \\
\text { special education language and } \\
\text { communication professionals. }\end{array}$ & 21 & $\begin{array}{l}\text { Quantitative, with descriptive } \\
\text { approach. } \\
\text { Instruments: Questionnaire. }\end{array}$ & $\begin{array}{l}\text { It reveals that most of the informants show } \\
\text { only basic and traditional knowledge, based on } \\
\text { outdated methodologies and lack of training } \\
\text { with respect to the most current techniques. }\end{array}$ \\
\hline
\end{tabular}


Table 2. Cont.

\begin{tabular}{|c|c|c|c|c|c|c|}
\hline $\mathbf{R Q}{ }^{*}$ & Author/Title & Year & Aim & Participants & Method & Results \\
\hline 2 & $\begin{array}{c}\text { Ramos, García, Olea, Lobos, \& Sáez } \\
\text { “Percepción docente respecto al } \\
\text { trabajo pedagógico durante la } \\
\text { COVID-19” }\end{array}$ & 2020 & $\begin{array}{l}\text { To learn about teachers' } \\
\text { perspectives on their role and the } \\
\text { teaching-learning process, } \\
\text { institutional support, and their } \\
\text { mental health state facing } \\
\text { COVID-19. }\end{array}$ & 10 & $\begin{array}{c}\text { Qualitative } \\
\text { Techniques: Interview. }\end{array}$ & $\begin{array}{l}\text { The perspectives of the teaching staff show the } \\
\text { need to find a balance between emotional and } \\
\text { academic characteristics, which reflects a } \\
\text { generalized affectation in the teaching staff at } \\
\text { the mental level due to the pandemic situation. } \\
\text { Conflictive emotions such as stress and } \\
\text { uncertainty are pointed out in the teaching } \\
\text { staff. }\end{array}$ \\
\hline $\begin{array}{c}1 \\
\text { and } \\
2\end{array}$ & $\begin{array}{c}\text { Hernández \& Álvarez } \\
\text { “Gestión educativa del confinamiento } \\
\text { por COVID-19: percepción del } \\
\text { docente en España” }\end{array}$ & 2021 & $\begin{array}{l}\text { To identify the topics of concern } \\
\text { for the educational community } \\
\text { during the closing of schools, to } \\
\text { identify and take into account the } \\
\text { future needs and concerns of the } \\
\text { educational community, and to } \\
\text { learn about and investigate the } \\
\text { proposals of the educational } \\
\text { community. }\end{array}$ & 8.726 & $\begin{array}{l}\text { Qualitative and Quantitative } \\
\text { Literature review and } \\
\text { statistical analysis. } \\
\text { Techniques: Questionnaire } \\
\text { and focus group. }\end{array}$ & $\begin{array}{l}\text { The teachers show their commitment to the } \\
\text { students and their concern for having } \\
\text { sustainable conditions for learning and } \\
\text { teaching in educational institutions, taking into } \\
\text { account not only the academic needs or } \\
\text { characteristics of the students but also their } \\
\text { physical and socioemotional state. Future } \\
\text { needs are identified as the establishment of an } \\
\text { appropriate distribution of space, taking into } \\
\text { account the classroom ratio and infrastructure } \\
\text { of the same, in addition to the general proposal } \\
\text { to provide greater support from the } \\
\text { educational administration. }\end{array}$ \\
\hline $\begin{array}{c}1 \\
\text { and } \\
2\end{array}$ & $\begin{array}{c}\text { Ardini, Barroso, \& Corzo } \\
\text { "Herramientas digitales de } \\
\text { comu-nicación en contexto COVID } 19 . \\
\text { El impacto en la relación } \\
\text { estudiantes-instituciones educativas } \\
\text { en Argentina" }\end{array}$ & 2020 & $\begin{array}{l}\text { To analyze the experiences carried } \\
\text { out with e-learning and to identify } \\
\text { perspectives and expectations } \\
\text { regarding the future of the current } \\
\text { educational system. }\end{array}$ & 194 & $\begin{array}{l}\text { Qualitative and quantitative, } \\
\text { with an exploratory approach. } \\
\text { Instruments: Questionnaire. }\end{array}$ & $\begin{array}{l}\text { The experiences gathered show the obstacles to } \\
\text { be overcome in order to achieve a full } \\
\text { education for students, as well as the } \\
\text { disadvantages and difficulties of online } \\
\text { teaching, such as lack of teacher support and } \\
\text { lack of information; the aim is to improve these } \\
\text { expectations in the future. }\end{array}$ \\
\hline 3 & $\begin{array}{l}\text { Karasel, Bastas, Altinay, Altinay, \& } \\
\text { Dabli } \\
\text { “Distance Education for Students with } \\
\text { Special Needs in Primary Schools in } \\
\text { the Period of COVID-19 Epidemic” }\end{array}$ & 2020 & $\begin{array}{l}\text { Intervention on online learning } \\
\text { applications in the field of special } \\
\text { education during COVID-19. }\end{array}$ & 10 & $\begin{array}{c}\text { Qualitative } \\
\text { techniques: Interview. }\end{array}$ & $\begin{array}{l}\text { There are no major advances in online } \\
\text { applications for students with SEN, and there } \\
\text { is a process of ignorance and abandonment in } \\
\text { online teaching for students belonging to } \\
\text { special education. Family participation and } \\
\text { involvement are scarcely and inadequately } \\
\text { reflected in the online teaching-learning } \\
\text { environment. }\end{array}$ \\
\hline
\end{tabular}


Table 2. Cont

Conduct a study on the use of ICT tools in people with DS (Down

Villamil, Paredes, \& Velázquez

3 "Estudio del uso de herramientas TIC en educación especial"
Syndrome), in order to know the training needs they present, the methods, and the use they make of them.
Qualitative and quantitative instruments: Questionnaire.

flexibility that enables its understanding and development, so that autonomy and freedom prevail in the development of the established processes, pointing this out as a process that facilitates and links the subject with DS. As training needs, a greater need for linkage between the subjects and ICTs is pointed out, as well as a greater investment of time and effort on the part of the teaching staff to adapt methodologies and rethink their usefulness.

It is shown that from the social perspective, there is a general lack of knowledge in the population, which presents large gaps in

Manso, González, Verdugo, \& Sánchez

"Análisis multimedia del impacto del confinamiento por COVID-19 en menores con autismo"
To know the overall effect of confinement on ASD students and the educational suggestions that can be used to stabilize the situation generated by the pandemic among these students.
Qualitative, with a

4 phenomenological approach

Observational study. knowledge about the incidence of measures such as confinement and the repercussions it has for children with ASD. Future educational suggestions include the importance of implementing socio-educational interventions for this type of students.

\section{Ceballos \& Sevilla}

“El Efecto del Aislamiento Social por el Covid-19 en la Conciencia 3 Emocional y en la Comprensión

Lectora. Estudio sobre la Incidencia en Alumnos con Trastornos de Aprendizaje y Menor Acceso a las Nuevas Tecnologías"

Amorim, Catarino, Miragaia, Ferreras, Viana, \& Guardiano

3
"Impacto del covid-19 en niños con Trastorno del Espectro Autista"
To know the effect of social isolation by the COVID-19 on 2020 emotional awareness and reading comprehension in students with learning disabilities

(ASD and ADHD students).
To know how ASD subjects and family members have experienced social isolation during the

quarantine period, taking into account emotional and behavioral issues.
Results indicate that isolation has a negative emotional impact on students with learning disorders. Likewise, emotional instability is observed in these students, which has an impact on the academic performance of the subjects and, therefore, on their reading

$$
\text { comprehension. }
$$

Qualitative
Q$$
\text { comprehension. }
$$

\section{Qualitative}

\section{Observational, cross-sectional,} and analytical-qualitative

study.Instruments:

Questionnaire.
It is shown that, as a consequence of isolation during the quarantine period, there is a high psychological impact on both the ASD subjects and their family members, with changes in their behavior and emotion management.

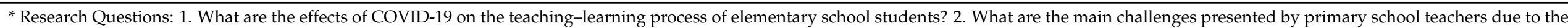
pandemic generated by COVID-19? 3. How does COVID-19 impact on the social and educational aspects of students with ASD in primary education? 


\section{Results}

\subsection{Identification of Selected Publications}

The articles presented in this section report different studies focused on the impact of COVID-19 in the educational field, which show an overview of different aspects such as the process of school closure and its educational-social consequences, teachers' perspectives on the teaching-learning process, and ICT needs and experiences in the training field. The main highlights of the documents obtained are listed in Table 1, indicating (1) author/s; (2) year of publication; (3) objectives; (4) participants; (5) methodology; and (6) results.

Therefore, the first and second study focuses on the international perspective on the process of school closures by COVID-19 and its educational-social consequences in general. The third, fourth, fifth, sixth, and seventh refer to teachers' perspectives on the teaching-learning process during the COVID-19 pandemic. The eighth, ninth, and tenth analyze the ICT needs and experiences in the training environment during the COVID-19 pandemic. Finally, the eleventh, twelfth, and thirteenth papers explore the repercussions of COVID-19 on ASD students.

\subsection{Description of the Articles Included}

The 13 studies included in the systematic review are highly diverse. First, the research conducted by Cáceres et al. [19] seeks to investigate the process of school closures from an international perspective and to analyze the possible educational and social consequences that may arise. Several key informants from twenty-three countries participated in the study, and their perceptions were subjected to a process of analysis based on several categories such as the times of execution, delay, or anticipation of the measures; the democratic and participatory nature of the educational measures that have been taken; the resources and infrastructure for carrying out distance training properly; the curricular, methodological, didactic, and evaluative adaptations; the perceptions shown by the teaching staff regarding the family environment; and the alternative proposals to this situation. Among the most relevant results, it should be noted that there are a great diversity of ways of dealing with the situation generated by COVID-19, with greater consequences for the most vulnerable population. In addition, the general perception prevails that the closing of the schools has been carried out timely, with decision-making based on a democratic and participatory response. Likewise, there is a positive attitude toward the implementation of curricular and methodological adaptations in general, taking into account that there are no detailed instructions on the aspects to be developed in this regard. Finally, most of the informants point out that, as a result of COVID-19, there are conflictive situations that have repercussions on the professional development of teachers as well as on the family environment, for which it is necessary to propose and generate suitable alternative proposals to alleviate these difficulties.

Other studies such as that of Sandín et al. [20] allow us to broaden the perspective centered on mental health by analyzing the impact that COVID-19 has had on it. The results obtained show the existence of common fears and concerns that arise in response to the current pandemic, with the fear of disease, contagion, and death, as well as fear related to social issues such as isolation and loneliness, work problems, and economic problems, being highlighted, among others. On the other hand, other different problems come to light that can have repercussions on emotional aspects such as fear, of which sleep problems, anxiety, stress, restlessness, nervousness, and constant worry stand out. Likewise, the media are considered to be one of the vehicles that can foster uncertainty in society and, therefore, may have an impact on the prediction of COVID-19.

Sevilla et al. [21] carried out a study analyzing the attitudes of teachers toward the inclusion of students with SEN. Regarding the results obtained, there is a generalized negative attitude on the part of teachers toward inclusive education, which differs from the attitude shown when referring to students with SEN, in which it is manifested in a more positive way. Thus, in contrast to the teachers' perception of students with SEN, the 
teaching staff shows a lack of training for the development of inclusive education, which is related to the lack of experience and the insufficient time they spend attending to the demands and needs of these students. It is important to point out that there are several factors that influence teachers' attitudes, including age and initial training. It has been shown that older teachers have spent more time since their initial training, which leads to a more traditional and disconnected conception regarding the adequate educational response to the demands generated by the COVID-19 in the field of SEN. Similarly, the educational level where teachers work is another factor that may affect their attitudes toward the situation, such as the pandemic, in order to meet the needs of students with SEN.

Other studies, such as that of Inga et al. [22], aim to know the perception of teachers in the city of Ozogues (Venezuela) regarding the COVID-19 pandemic in reference to psychosocial aspects and their work as teachers. Among the results obtained, a great negative repercussion in the field of education is highlighted in relation to the impact of the pandemic, finding personal affectations and limitations in teachers; placing as main factors the insufficient knowledge on the part of the teaching staff about ICT, the scarce economic resources to be able to have technological resources among students, and the drastic change of life generated by the COVID-19 situation. The concern generated by the teaching staff is centered on the inadequate technological management available to them in the country, as well as the lack of knowledge in this regard. Similarly, an alternative is to encourage habits that favor an adequate response to conflictive situations and to manage moods in order to learn to coexist with the frustrations and fears that arise in circumstances typical of this pandemic.

Sanahuja et al. [23] developed their study with the aim of discovering whether communication and language professionals and special education teachers have been trained or informed about various learning regulation strategies, as well as investigating the level of mastery and development of these strategies in the classroom by these professionals. Regarding the results obtained, it is important to contrast in times of COVID-19 whether teachers specializing in SEN have acquired or know strategies for self-regulation and personalization of teaching, these being important when acting and intervening with students under current circumstances. Therefore, the results obtained reveal that most of the trainees show a basic and traditional knowledge of learning regulation and teaching personalization strategies, while, on the contrary, there is a greater lack of knowledge of the most innovative proposals. Thus, there is a lack of continuous and insufficient training among professionals in the field of special education, who tend to use more traditional techniques and strategies, since they are the best known.

Studies such as the one conducted by Ramos et al. [24] set as the main objective of the research the knowledge of teachers' views on their role and the teaching-learning process, the support of institutions, and the state of mental health in the face of COVID-19. The results obtained show that the predominant perception of the teaching staff when it comes to understanding their role is centered mainly on the emotional needs of the school community; there must be a balance in attending to the emotional as well as the academic characteristics. Regarding the perspective of the teaching-learning process, emphasis is placed on the need to acquire technological competencies in order to carry out a curricular action that is developed according to the needs presented in the context. Likewise, it is emphasized that the teaching-learning process in the current scenario requires access to the Internet, as well as other technical resources that are only available to a certain group of students. This leads to high work demands among teachers, which are accompanied by conflicting emotions such as stress and uncertainty.

The research carried out by Hernández and Álvarez [3] has three main objectives: to investigate the issues that have been of concern to the educational community during the closure of schools during the 2019/2020 academic year, to identify the future needs and concerns of the educational community for the 2020/21 academic year, and to find out the proposals of the educational community for the next 2020/21 academic year. The results obtained reflect an educational panorama that is situated in a duality from concern 
to hope, taking into account that during the COVID-19 pandemic, all the weaknesses that the educational system had been bringing with it have been exposed. They also point out the difficulty of adapting to new technological needs, but the need for transformation allows them to support the current situation from a hopeful perspective. Teachers and families show general dissatisfaction with the pandemic, arguing the need to reinforce the structures of the educational system in terms of technological and personal resources. Similarly, future needs are identified as the establishment of an appropriate distribution of space, taking into account the classroom ratio and infrastructure of the same, in addition to presenting as a general proposal a greater support from the educational administration.

Ardini et al. [25] focus their research on the analysis of the teaching-learning experiences carried out with the virtual format, as well as on the identification of perspectives and expectations regarding the future of the educational system presented in the current scenario. From the results obtained, it can be observed that, with respect to the conditions of access to technologies for the development of online education, a large majority of informants had no previous contact with these technologies and had not received specific training. In this regard, a general dissatisfaction with the online learning experience was obtained, highlighting the variation of the daily routine in activities and inadequate time management, giving rise to negative emotions that include feelings of frustration in the majority, confusion, or boredom, accompanied to a lesser extent by curiosity and tension. Disadvantages and difficulties of online teaching-learning experiences are mainly the lack of teacher support and the absence of information, as well as the lack of space to carry out or the necessary equipment. In this regard, as future expectations, it is necessary to take into account the shortcomings mentioned and try to work on them for a possible improvement.

Another study such as that of Karasel et al. [26] is carried out with the aim of knowing the intervention carried out through the eLearning system and digital technologies that has been carried out in the field of special education during the pandemic. One of the results obtained shows that in the field of special education, there is a generalized lack of knowledge and consequently great difficulty and abandonment by students of the eLearning modality depending on the needs raised by this situation. The applications developed so far are not the necessary ones to cover the needs of these students, and the level of knowledge that families have about them is insufficient. Therefore, the scarce participation and involvement of families in the field of online teaching-learning is highlighted, as well as the inadequate use of existing materials and applications for this type of students.

The research carried out by Villamil et al. [27] aims to carry out a study on the use of ICT tools by people with Down syndrome, as well as to know their training needs and the use they provide them with. The results obtained in this research show that people with Down syndrome are common users in the field of ICT. In the teaching environment, there is a flexibility that facilitates their understanding and development, so that self-determination and freedom prevail in the development of processes that facilitate the comprehensive training of students with Down syndrome. This brings with it a workload for the teacher or the special education professional who carries out the curricular adaptations, as well as an increase in the investment of time in them, placing this charge sometimes as a disadvantage in the use and adaptation of ICT by the teaching staff.

Manso et al. [28] focus their research objectives on knowing the general influence of confinement on the development of ASD students and the educational suggestions that can be proposed to stabilize the situation generated by the pandemic among these students. Results obtained show that, from the social perspective, there is a general lack of knowledge in the population about the incidence of the measures adopted in the face of confinement and its repercussions for students with ASD. Similarly, it is observed that the influence may differ depending on the subject in relation to the personal, social, and family characteristics that are present in this situation, which shows the importance of developing socio-educational interventions in ASD students, in order to stabilize the situation generated by the pandemic in this student body. 
Other studies such as those by Ceballos and Sevilla [29] aim to determine the effect of social isolation due to COVID-19 on the emotional awareness and reading comprehension of students with learning disabilities. The results obtained indicate that isolation is provoking a negative emotional impact on students with learning disabilities, which leads to feelings of frustration, exhaustion, sadness, irritability, anguish, and nervousness, all of them accompanied by a general feeling of uncertainty. Likewise, emotional instability is observed in these students, which also has repercussions for their academic performance. In relation to reading comprehension, a generalized worsening has been observed. Although students have improved their reading at home from the quantitative point of view, emotional difficulties and the change in the situation in which they receive their education have worsened the level of reading comprehension from the qualitative point of view. As relevant data, the problem of access to ICTs by the students to be able to face the present situation of social isolation is pointed out, together with a generalized burden that both teachers and parents are carrying out as an additional effort due to COVID-19 and its consequences.

Finally, the research by Amorim et al. [30] aimed mainly to know the way in which ASD subjects and their families experienced social isolation during the established period of quarantine, addressing issues at the emotional and affective level of all of them. The results obtained show a high rate of modification in the behavior of the ASD subjects, presenting negative alterations in their behavior toward the members with whom they lived and toward themselves, which leads to an increase in anxiety for the family members and, in addition, an increase in stress for the ASD students. Significantly, there are differences between the students who during the quarantine period have followed certain routines and those who have not, showing lower levels of anxiety and stress in the students who have followed these routines. In short, in general terms, there is a psychological and behavioral impact on ASD students and their families, with the predominant cause being the situation caused by COVID-19 and its repercussions on these subjects.

\section{Discussion}

The results of the research, as we have seen in the aspect related to the impact of COVID-19 in primary education, show that several authors agree on the idea that there is a general impact on the entire educational system [28,31-33], which violates such important fundamental rights as the right to education [34,35], also providing the differentiating fact of the degree of impact on the population according to the sociocultural level, placing the most vulnerable groups as the most affected [1,36].

In the section on the role of teachers in primary education during the COVID-19 pandemic, the general idea is that the teaching function is a term that generates different conceptions in relation to the training and identity of these professionals [6,37]. At present, this term has again been subjected to debate, alluding to the nature of their training given the circumstances and the necessary shaping of identity with all this process of change [12,38]. In addition, remote work is highlighted as a factor that clearly belongs to the model of change that is coming and to which teachers have been forced to respond urgently $[39,40]$. Accordingly, the importance of the role of families, in addition to the educational institutions, as an element of change and social construction [10] is also mentioned, and families are seen as determining factors in the educational process of students [15].

Finally, in the section related to students with ASD in times of COVID-19, differences in the characteristics of ASD and the implications that they have entailed are discussed, which significantly differ depending on the author and the initial conception [14]. In this regard, a generalized conception is presented on the affectation in the different socioeducational aspects of ASD students produced by COVID-19 [40]. In addition, given the aforementioned effects, the conclusion is reached to propose specific guidelines as a strategy to mitigate these adverse effects [33].

Therefore, in relation to the initial questions posed and the research objectives indicated, the following conclusions have been obtained: 
- What are the effects of COVID-19 on the teaching-learning process of elementary school students?

The first question established in the development of this work is to know the effects of COVID-19 on the learning process of primary education students, and it is clear that there are major repercussions in this area. The right to education is one of the problems identified, affecting different sectors of the population and placing greater emphasis on people belonging to the most vulnerable social groups. Likewise, the conceptual change of traditional education has been promoted, entailing the need to establish an urgent transition from traditional education to virtual education. This transition does not leave any group indifferent, with repercussions for the teaching, student, and family spheres, with the emergence of social inequalities that went unnoticed with the previous model of traditional education. The digital gap is pointed out as one of the elements that trigger these social inequalities, as well as the need to promote training and general knowledge about the usefulness of the tools and the technological tools for study and work. The repercussions are found in both teachers and students, the latter including their family context and, in addition, finding differential connotations in relation to their economic level or social status. Accordingly, the need to improve the training aspects of this new virtual education and the elements that accompany it is reaffirmed, as well as the need to eliminate social barriers so that this teaching model may reach all students and thus enable a full education for all.

- What are the main challenges presented by primary school teachers due to the pandemic generated by COVID-19?

The second objective of the study was to investigate the demands and challenges presented to primary education teachers in relation to the COVID-19 pandemic. In this regard, the need to show the aspects involved in the change from a traditional teaching modality to a virtual modality has been highlighted, which has led allusions to the established perception of the teacher's role and professional competencies, noting certain variations produced by the aforementioned change. As a relevant aspect, it is necessary to highlight the new form of work that goes with this change of educational modality, entailing the need to develop remote work on the part of the teachers. It is noted that there are different limitations that attend this new form of work, presenting, at the present time and given the urgency and situation that occurs, aspects of limited positive character and a majority of negative character, although they provide different perceptions that could be an aspect of improvement in its future development. Therefore, given the aforementioned circumstances, it is important to mention the concept of social and professional welfare to be undertaken and its different areas, in which repercussions have been seen, as well as the different situations that have led to this whole process of change in the teaching staff. In addition, the appearance of COVID-19 has led to the role played by the family in the teaching-learning process being enhanced even more since, given the circumstances, such as the closure of school institutions, they have been forced to strengthen ties and establish a much stronger family union than before, being decisive in overcoming the new limitations that have arisen in the teaching-learning process of their children.

- How does COVID-19 impact on the social and educational aspects of students with ASD in primary education?

With regard to the third objective, we can see how COVID-19 has generated a number of limitations that have been especially increased for this type of students, with serious effects on the personal, educational, and family environments of ASD individuals. Thus, situations are observed that promote changes in contexts and routines of these students, thus leading to the modification of their educational development, leading to various repercussions for the individual's personal level.

In this regard, a set of contributions are also collected with the purpose of overcoming the obstacles or problems established in the socio-educational areas previously mentioned, thereby facilitating the social and educational integration of these students into the pan- 
demic situation. It is evident that, with a view to the future of the educational systems of the different countries, the methodological, organizational, and resource implications, as well as the educational contents and objectives themselves, have been significantly questioned, which require reformulation with a view to future needs.

In this sense, we can point out challenges such as economic investment in the training of teachers and students in new technologies, the provision of computer equipment and updated software, the insertion of modifications in the curricula and skills to be developed in digital students [41], or the empowerment of new online socialization channels and the training of society as a whole for its proper use through community programs and not just school programs [42], etc.

Finally, as a limitation of the present review, it is worth mentioning the wide range of studies that have been carried out in this area since the emergence of the pandemic and the consequent need to update and contrast future results. Although this work tries to show a general vision about the subject, it will be convenient to continue advancing in the study of the different educational stages and different disabilities or vulnerable situations in which the pandemic has affected the educational reality, delving into the analysis of specific educational needs presented by each group and using different research methodologies that suggest concrete educational proposals and specific action guidelines that respond to the new needs in the field of educational inclusion.

Author Contributions: Conceptualization, J.J.S.A., A.L.d.l.R., R.G.C. and A.V.S.; methodology, J.J.S.A., A.L.d.1.R. and R.G.C.; software, A.L.d.l.R. and A.V.S.; formal analysis, J.J.S.A., A.L.d.l.R. and R.G.C.; investigation, J.J.S.A., A.L.d.1.R., R.G.C. and A.V.S.; resources, A.V.S.; data curation, J.J.S.A., A.L.d.l.R., R.G.C. and A.V.S.; writing—original draft preparation, A.L.d.l.R.; writing—review and editing, J.J.S.A., A.L.d.l.R., R.G.C. and A.V.S.; visualization, J.J.S.A., A.L.d.l.R., R.G.C. and A.V.S.; supervision, J.J.S.A., R.G.C. and A.V.S.; project administration, J.J.S.A., R.G.C. and A.V.S. All authors have read and agreed to the published version of the manuscript.

Funding: This research received no external funding.

Institutional Review Board Statement: Not applicable.

Informed Consent Statement: Not applicable.

Conflicts of Interest: The authors declare no conflict of interest.

\section{References}

1. Interrupción Educativa y Respuesta al COVID-19. Available online: https:/ / es.unesco.org/covid19/educationresponse (accessed on 23 May 2021).

2. Cáceres, I. Educación en el escenario actual de pandemia. Rev. Utopía Prax. Latinoam. 2020, 5, 11-13.

3. Hernández, J.; Álvarez, J.F. Gestión educativa del confinamiento por COVID-19: Percepción del docente en España. Rev. Española Educ. Comp. 2021, 38, 129-150.

4. Chávez, H. Modelo socioemocional frente a la COVID-19 para estudiantes de educación primaria. Rev. Científica Fac. Humanid. Educ. Comun. 2020, 2, 4-9.

5. Corral, D.; De Juan, J. La educación al descubierto tras la pandemia del COVID-19: Carencias y retos. Rev. Digit. Comun. Aularia 2021, 2, 21-28.

6. García, F.; Corell, A.; Abella, V.; Grande, M. La evaluación online en la Educación Superior en tiempos de la COVID-19. Educ. Knowl. Soc. 2020, 12, 1-26.

7. Cóndor, O. Educar en tiempos de COVID-19. CienciAmérica 2020, 2, 1-7.

8. Cotonieto, E.; Martínez, R.; Rodríguez, R. Reflexiones sobre la educación en tiempos de COVID-19: Retos y perspectivas. Rev. Saberes Educ. 2021, 1, 116-127. [CrossRef]

9. Echeita, G. La Pandemia del COVID-19. ¿Una oportunidad para pensar en cómo hacer más inclusivos nuestros sistemas educativos? Rev. Int. Educ. Justicia Soc. 2020, 1, 7-16.

10. Martínez, L.; Azcona, A. Escuela Post-Covid: La oportunidad de repensar la educación en clave inclusiva. Rev. Int. Educ. Justicia Soc. 2020, 3, 12-34.

11. Carmenate, I.; Rodríguez, A. Repercusión psicológica en niños con trastorno del espectro autista durante el confinamiento por COVID-19. Rev. Médica Multimed 2020, 24, 690-706.

12. Sánchez, M.; Martínez, A.; Torres, R.; Servín, M.; Hernández, A.; Benavides, M.; Jaimes, C.; Rendón, V. Retos educativos durante la pandemia de COVID-19: Una encuesta a profesores de la UNAM. Rev. Digit. Univ. 2020, 2, 2-25. 
13. Alcantud, F.; Alonso, Y. Trastorno del espectro autista y necesidades educativas especiales: Una mirada diferente. Fedune 2015, 4, 3-18.

14. Demósthene, Y.; Campo, C. Educación y entorno familiar de las personas con trastorno del espectro de autismo ante la pandemia COVID-19. Rev. Científica Cienc. Tecnol. 2020, 20, 33-39.

15. Dans, E. The coronavirus pandemic has unleashed a revolution in education: From now on, blended learning will be the benchmark. Rev. Forbes 2020, 23, 1-5.

16. Chadegani, A.; Salehi, H.; Yunus, M.; Farhadi, H.; Fooladi, M.; Farhadi, M.; Ebrahim, N. Una comparación entre dos colecciones principales de literatura académica: Web of Science y bases de datos Scopus. Asian Soc. Sci. 2013, 9, 18-26.

17. Manterola, C.; Astudillo, P.; Arias, E.; Claros, N.; Sistema, G. Revisiones sistemáticas de la literatura. Que se debe saber acerca de ellas [Revisión sistemática de la literatura: Qué se debe saber sobre ellas]. CirugIuna Española 2013, 91, 149-155. [CrossRef]

18. Hutton, B.; Cátala, F.; Moher, D. La extensión de la declaración PRISMA para sistema de revisión sistemática que incorporan metaanálisis en rojo: PRISMA-NMA. Med. Clínica 2016, 147, 262-266. [CrossRef]

19. Cáceres, J.; Jiménez, A.; Martín, M. Cierre de escuelas y desigualdad socioeducativa en tiempos del COVID-19. Una Investigación exploratoria en clave Internacional. Rev. Int. Educ. Justicia Soc. 2020, 9, 199-221.

20. Sandín, B.; Valiente, R.; García, J.; Chorot, P. Impacto psicológico de la pandemia de COVID-19: Efectos negativos y positivos en población española asociados al periodo de confinamiento nacional. Rev. Psicopatología Psicol. Clínica 2020, 25, 1-22. [CrossRef]

21. Sevilla, D.; Martín, M.; Jenaro, C. Actitud del docente hacia la educación inclusiva y hacia los estudiantes con necesidades educativas especiales. Innovación Educ. 2018, 18, 115-141.

22. Inga, M.; García, D.; Castro, A.; Erazo, J. Educación y COVID-19: Percepciones docentes para enfrentar la pandemia. Rev. Arbitr. Interdiscip. Koin. 2020, 10, 1-12.

23. Sanahuja, A.; Sánchez, L.; Ruiz, P. Estrategias de autorregulación y personalización de la enseñanza: Estudio piloto sobre las competencias de los profesionales de comunicación y lenguaje y de educación especial. Rev. Educ. Innovación Form. 2020, 3 , 175-193.

24. Ramos, V.; García, H.; Olea, C.; Lobos, K.; Sáez, F. Percepción docente respecto al trabajo pedagógico durante la COVID-19. CienciAmérica 2020, 9, 13-35.

25. Ardini, C.; Barroso, M.; Corzo, L. Herramientas digitales de comunicación en contexto COVID-19. El impacto en la relación estudiantes-instituciones educativas en Argentina. Rev. ComHumanitas 2020, 11, 98-122.

26. Karasel, N.; Bastas, M.; Altinay, F.; Altinay, Z.; Dagli, G. Distance Education for Students with Special Needs in Primary Schools in the Period of COVID-19 Epidemic. Propósitos Represent. 2020, 8, 34-41.

27. Villamil, J.; Paredes, M.; Velázquez, J. Estudio del uso de herramientas TIC en educación especial. Ser. Inf. Técnicos DLSI1-URJC 2020, 4, 3-56.

28. Manso, L.; González, M.; Verdugo, S.; Sánchez, M. Análisis multimedia del impacto del confinamiento por COVID-19 en menores con autismo. Rev. Ludomedia 2021, 7, 85-94.

29. Ceballos, N.; Sevilla, S. El Efecto del Aislamiento Social por el Covid-19 en la Conciencia Emocional y en la Comprensión Lectora. Estudio sobre la Incidencia en Alumnos con Trastornos de Aprendizaje y Menor Acceso a las Nuevas Tecnologías. Rev. Int. Educ. Justicia Soc. 2020, 9, 1-13.

30. Amorim, R.; Catarino, S.; Miragaia, P.; Ferreras, C.; Viana, V.; Guardiano, M. Impacto del covid-19 en niños con Trastorno del Espectro Autista. Rev. Neurol. 2020, 71, 285-291. [CrossRef]

31. Rujas, J.; Feito, R. La educación en tiempos de pandemia: Una situación excepcional y cambiante. Rev. Sociol. Educ. RASE 2020, $14,4-13$.

32. Aldao, M.; Clérico, L. La Igualdad "Reformada": La Igualdad "Desmarcada". Formación de Jueces: Su Adecuación a un Modelo de Sociedad Igualitaria; EUDEBA: Universidad de Buenos Aires, Buenos Aires, Argentina, 2019; pp. 193-216.

33. Ruiz, G. Marcas de la pandemia: El derecho a la educación afectado. Rev. Int. Educ. Justicia Soc. 2020, 9, 45-59. [CrossRef]

34. Zubillaga, A.; Gortazar, L. Covid-19 y Educación: Problemas, respuestas y escenarios. Cotec 2020, 3, 1-38.

35. Atkinson, D. Theorizing how student teachers form their identities in initial teacher education. Br. Educ. Res. J. 2004, 30, 379-394. [CrossRef]

36. Soreide, G. Narrative construction of teacher identity: Positioning and negotiation. Teach. Teach. Theory Pract. 2006, 12, 527-547. [CrossRef]

37. García, M. La docencia desde el hogar. Una alternativa necesaria en tiempos del COVID-19. Rev. Multidiscip. Innovación Estud. Apl. 2020, 5, 304-324.

38. Martín, M.; Tamayo, M. Funciones básicas de la familia. Reflexiones para la orientación psicológica educativa. Rev. EduSol 2013, 13, 60-71.

39. Gutiérrez, M.; López, J. Autoconcepto, dificultades interpersonales, habilidades sociales y conductas asertivas en adolescentes. Rev. Española Orientación Psicol. 2015, 26, 13-27.

40. Hens, K. The many meanings of autism: Conceptual and ethical reflections. Dev. Med. Child Neurol. 2019, 61, 1-19. [CrossRef]

41. OCDE. Combating Covid 19's Effect on Children; OCDE: Paris, France, 2020.

42. Iglesias, E.; González, J.; Lalueza, J.L.; Esteban, M. Manifiesto en Tiempos de Pandemia: Por una Educación Crítica, Intergeneracional, Sostenible y Comunitaria. Rev. Int. Educ. Justicia Soc. 2020, 3, 181-198. [CrossRef] 